УДК 633.179:631.559:631.5(477) $\quad$ DOI 10.31210/visnyk2018.03.11
(C) 2018

Кулик М. І., кандидат сільськогосподарських наук

Полтавська державна аграрна академія

\title{
АНАЛІЗ КОМПЛЕКСНОГО ВПЛИВУ АГРОЗАХОДІВ НА УРОЖАЙНІСТЬ ПРОСА ПРУТОПОДІБНОГО В УМОВАХ ЦЕНТРАЛЬНОГО ЛІСОСТЕПУ УКРАЇНИ
}

\author{
Рецензент - доктор сільськогосподарських наук, професор В. Л. Курило
}

Обтрунтування менеджменту посівів проса прутоподібного (світчграсу), за встановлення найбільш впливових агрозаходів на урожайність, є актуальним питанням (для удосконалення елементів технологіі вирощування), щчо потребує детального вивчення.

Визначено, щуо залежно від схем передпосівної підготовки трунту найбільша урожайність світчграсу (від 12,3 до 15,5 m/2а) зафіксована при проведенні двох культивацій навесні з коткуванням трунту до- $i$ після сівби на фоні напівпарового осіннього обробітку трунту. Збільшення кількості культивачій у весняний період не має впливу на продуктивність культури.

За роки проведення досліджень кращиими варіантами виявилося вирощування світчграсу з шириною міжряддя 45 см і застосування весняного підживлення рослин нормою азоту 30-45 кг/га. Внесення зменшених та збільшених норм азоту не призводить до суттевого підвищення урожайності, а й навіть змениує даний показник. Поряд з ичм, на варіантах із більш ширшими міжряддями - 60 см істотної різниці між внесенням $N_{45}$ i $N_{60}$ не виявлено.

Найбільшу урожайність світчграсу отримали за норми висіву насіння 3,0 млн. н./2а, як зменшення, так $i$ збільшення даного показника призводить до зниження продуктивності культури. В той же час, порівняно із ранньо-, пізньовесняними та літніми строками сівби відмічено збільшення урожайності культури при весняному строкові сівби.

Ключові слова: світчграс, обробіток трунту, ширина міжрядь, строк сівби, підживлення, урожайність.

Постановка проблеми. На даний час одним із головних та першочергових завдань у системі управління енергетикою України для ії подальшого сталого розвитку, підвищення рівня енергетичної безпеки постає проблема розроблення та реалізації політики забезпечення існуючих потреб країни в паливно-енергетичних ресурсах (ПЕР). Основні вимоги при цьому повинні враховувати: дотримання вимог раціонального використання ПЕР, зменшення негативного впливу на довкілля з урахуванням взятих Україною міжнародних природоохоронних зобов'язань, соціально-економічних пріоритетів, обмежень тощо.

Незважаючи на те, що енергоефективність без- заперечно є одним із пріоритетів енергетичної політики України, використання енергії залишається надмірним, а результаттивність впровадження заходів 3 енергоефективності, за міжнародними стандартами - порівняно низьким. Для порівняння - обсяг енергії, що використовується для виробництва одиниці товарів і послуг (тобто на одиницю ВВП) в Україні перевищують рівень: Великобританії- в 4,8 рази; Туреччини - у 3,8 рази; Польщі - у 3 рази; Білорусії - у 1,8 рази; середній показник для Свропейського Союзу-у 3,8 рази; в цілому для світу - у 2 раза [5].

Для зменшення використання ПЕР, та виконання своїх зобов'язань в нашій країні було розроблена «Енергетична стратегія України до 2030 року» [4], що передбачає розвиток біоенергетики, та динамічне зростання обсягів використання енергіï біомаси в 2015 р. - до 5 млн. тонн умовного палива (т у. п.), або це 2,5 \% від загального енергоспоживання, а в 2030 році - до 20 млн т у. п. або до $10 \%$.

Для реалізації програми розвитку біоенергетики в Україні наявні всі необхідні передумови, в першу чергу-грунтово-кліматичні умови, які сприяють отриманню високої врожайності енергоємної біомаси енергетичних культур. По-друге, використання адаптивних технологій вирощування на маргінальних землях енергетичних культур, вдосконалення існуючих, відповідна переробка рослинної сировини й використання біопалива в ПЕК забезпечить зростання частки біоенергетики у загальній структурі енергетики України та значно зменшить енергозалежність нашої країни. І як результат - зменшення використання непоновлюваних енергоресурсів, на фоні зростання попиту на альтернативні джерела енергії, що в перспективі сприятиме розвитку національної економіки та зростанню добробуту населення.

Враховуючи вищевикладене, на сьогоднішній день актуальними питаннями розвитку нової галузі - біоенергетики є:

- пошук шляхів здешевлення виробництва різних видів біосировини,

- удосконалення агрозаходів вирощування 
енергетичних культур,

- розробка нових техніко-економічних рішень,

- формування необхідної інфраструктури з метою ефективнішого використання рослинних енергетичних ресурсів і переробки їх біомаси для отримання рідкого (біоетанол, біобутанол), газоподібного та твердого біопалива (гранули, брикети тощо).

Аналіз основних досліджень і публікацій, у яких започатковано розв'язання проблеми. Всебічне вивчення проса прутоподібного (Panicum virgatum L.), як сировини для виробництва біопалива пов' язано з адаптивними властивостями культури, багаторічним циклом життя, стійкістю до шкідників і хвороб та високим потенціалом щодо формування потужної вегетативної надземної маси за одночасно, порівняно із міскантусом гігантським, низькими енергетичними затратами на вирощування, можливістю консервації карбону і зменшення викидів вуглекислого газу [16-19, 24, 30, 39, 40].

Окрім цього визначено, що просо прутоподібне - це основна енергетична культура другого покоління, яка здатна підтримувати або поліпшувати якість землі за рахунок впливу на грунтовий вуглець [12, 32, 34].

Встановлено, що для забезпечення потужного фітоценозу проса прутоподібного 3 довготривалим використанням (понад 20 років) необхідно проводити обгрунтований менеджмент посівів протягом кількох років $[17,26]$.

Підготовка грунту для вирощування проса прутоподібного передбачає знищення бур'янів та очищення поля для послідуючої сівби культури. Для сівби рекомендують використовувати очищене, з високою схожістю насіння [28, 39]. Високостеблові культури, як попередник можуть загострити проблему забур'яненості, та рівномірності сівби. Також визначено, що насіння проса прутоподібного можна висівати в необроблений «no till» або вирівняний, чистий і прикоткований грунт на глибину близько 1 см [14, 27].

W. R. Ocumpaugh із співавторами [28] порівняли ширину міжрядь 15, 30 і 50 см і встановили, що за посушливих умов посіви проса прутоподібного 3 широким міжряддям мали вищу урожайність. Автори визначили, що ширина міжрядь - важливий фактор для формування урожайності світчграсу. Звужені рядки прискорить закриття міжряддя фітомасою, що поліпшує доступ світла до рослин протягом вегетаційного періоду і як наслідок підвищує урожайність культури. Це також зменшить необхідність боротьби із забур'яненістю поля. В той же час у густого травостою більша вірогідність ураження хворобами і вилягання фітоце- нозу. Ці висновки знайшли підтвердження у дослідженнях інших науковців, які встановили, що на звужених міжряддях виникає проблема самопроріджування світчграсу, що зменшує загальний об' єм біомаси культури [25].

D. I. Bransby та інші встановили [13], що після першого року вирощування при широкому міжрядді (80 см) сорт Alabama давав більший урожай, порівняно 3 вузьким (20 см). Підвищення урожаю біомаси проса прутоподібного особливо було помітним через декілька років вирощування.

На противагу цьому, вітчизняні вчені визначили [11], що при вирощувані світчграсу на енергетичні цілі в умовах Правобережного Лісостепу максимальний вихід біомаси культури в середньому за два роки (при сівбі у 2-гу декаду квітня та 3 шириною міжрядь 30 см) становив 5,9 т/га, за сівби в 3-й декаді травня 3 шириною міжрядь 15 см отримали найменшу урожайність - 3,4 т/га.

Поряд 3 цим, попередніми нашими дослідженнями проведеними в умовах центрального Лісостепу України встановлено [6], що на висоту рослин світчграсу першого року вегетації більший вплив мають сортові особливості за ширини міжрядь 30 см, а при 45 см ця різниця зникає, що може свідчити про те, що зі збільшенням площі живлення рослин знижується їх конкуренція за мінеральні поживні речовини й спостерігається вирівнювання за висотою у досліджуваного сорту світчграсу. Дана тенденція зберігалась і стосовно густоти рослин на одиниці площі. Це вказує на те, що даний показник (густота рослин) може бути більш надійним параметром, ніж висота в оцінці продуктивності сортів світчграсу для виробництва біомаси.

Також автором публікації було визначено [7], що в умовах центральної частини Лісостепу високий потенціал врожайності сухої вегетативної маси сортів проса прутоподібного Форесбург i Кейв-ін-рок третього і четвертого року вегетації забезпечується при ширині міжряддя 45 см, суттєво меншу врожайність зафіксовано під час вирощування даних сортів на вужчих міжряддях (15 і 30 сантиметрів).

Поряд 3 цим, М. Я. Гументик вивчив спосіб вирощування проса прутоподібного при комбінованій ширині міжряддя $(0,4 \times 0,35 \times 0,45)$, що забезпечує густоту рослин на рівні 90 шт./м.п. При цьому отримали найвищі показники за висотою, густотою стеблостою та продуктивністю культури [1].

Авторами встановлено [27, 33, 36], що строки сівби - важливий фактор успішного вирощування проса прутоподібного. Доведена ефективність як раннього, так і пізнього строку сівби культури $[29,39]$. 


\section{СІЛЬСЬКЕ ГОСПОДАРСТВО. РОСЛИННИЦТВО}

Перевагою ранньої сівби є виведення насіння проса прутоподібного зі стану спокою через прохолодні і вологі грунтові умови [27]. При цьому зростає шанс достатнього зволоження для проростання насіння, появи сходів i розвитку коренів другого порядку за рахунок доступної вологи 3 грунту. Також, до закінчення вегетації просо прутоподібне матиме достатньо часу для росту і розвитку рослин, проходження усіх етапів органогенезу, підвищуючи свою зимостійкість. Основна проблема ранньої сівби - низька температура грунту, що призводить до повільного проростання насіння та росту проростків проса прутоподібного [33].

У той же час за вивчення енергетичних культур в умовах Полісся В.В.Думичем із співавторами було встановлено [3], що грунтово-кліматичні умови регіону вирощування є сприятливими для вирощування проса прутоподібного сорту Картадж. Оптимальний строк сівби та норма висіву насіння забезпечують необхідні умови для росту i розвитку рослин, а його продуктивність культури в значній мірі залежить від вологості грунту.

Інші вчені [10] визначили, що просо прутоподібне за весняного строку сівби на другий рік вегетації формує врожайність від 8,7 до 11,5 т/га сухої біомаси, а літній строк сівби суттєво зменшує цей показник. Авторами встановлено, що оптимальні умови для світчграсу можна створити певними агротехнічними заходами та засобами, підбираючи сорти з урахуванням агробіологічних особливостей регіону й погодних умов року.

За встановлення оптимального строку сівби проса прутоподібного необхідно враховувати доступну кількість вологи в грунті, відсоток іiі використання рослинами проса прутоподібного для формування одиниці сухої маси з урахуванням площі живлення (ширини міжряддя) [22].

Щодо вивчення добрив на посівах проса прутоподібного було встановлено, що в перший рік не рекомендується використовувати добрива (особливо азот), оскільки це активізує ріст бур'янів. На легких грунтах і в південних регіонах можна внести незначну кількість азоту під час вегетаційного періоду першого року вирощування культури. В наступні роки удобрювати необхідно пізніше, коли бур'яни менше конкурують iз світчграсом. Якщо азотне добриво не використане повністю до кінця вегетаційного періоду його залишок може збільшити забур'яненість наступної весни. Просо прутоподібне добре вбирає органічний азот, оскільки найвищі коефіцієнти приросту рослин проявляються за найвищої мінералізації органічного азоту[27]. Високий рівень мінералізації і споживання проса прутоподібного може призвести до вилягання, проблеми, яку зафіксовано в Англії та Канаді. На важких грунтах 3 високим вмістом азоту просо прутоподібне часто не реагує на азот протягом декількох років після першого року вирощування $[14,31]$. При високому вмісті азоту в грунті після посухи в Техасі також було підтверджено вилягання посівів проса прутоподібного [28].

Потреба проса прутоподібного в азоті становить лише 50 кг на гектар [35]. Це знайшло підтвердження у дослідженнях американських вчених [27], ними було розроблено норми внесення азотних добрив для проса прутоподібного в якості пасовищної культури. Залежно від кількості опадів норми добрив змінюються між 50 і 100 кг на гектар азоту на територіях відповідно з 450 i 750 мм опадів на рік. Інші вчені [30] визначили, що для укорінених посівів світчграсу найкращим принципом для внесення азотних добрив $\epsilon$ внесення в нормі, еквівалентній коефіцієнту отриманню урожаю, який рівний близько 6-10 кг на тону сухої речовини для осіннього збору урожаю i 4-8 кг - для весняного.

Більшість досліджень з вивчення застосування фосфорних дорив на посівах проса прутоподібного показують, що культура не реагує на фосфор, навіть на малопродуктивних грунтах [20, 21, 28].

Результати досліджень D. Wang, D. S. Leabauer, M. C. Dietze [38] продемонстрували потенціал проса прутоподібного за вирощування як в монокультурі, так і в сумішах у широкому географічному діапазоні. Монокультура має суттєву позитивну реакцію на азотне підживлення та опади для новостворених (віком до 3 років) та зрілих посівів (більше 3 років) для усіх екотипів світчграсу. Отримані результати дозволяють припустити, що внесення азоту у підживлення сприяє збільшенню врожайності в монокультуpax, a сумішах підживлення $є$ альтернативним джерелом азоту для рослин.

Вітчизняних дослідження щодо застосування добрив для підживлення проса прутоподібного в умовах Лісостепу України - обмаль, окрім [8]. Автор публікації встановив, що на деградованих грунтах (вміст гумусу 2,07\%) найбільша врожайність сухої надземної вегетативної маси проса прутоподібного сорту Кейв-ін-рок третьогоп'ятого року вегетації формується за проведення дворазового підживлення препаратом групи «Кристалонів» у періоди відновлення вегетації та весняного кущіння рослин.

Цю думку підтверджують К. P. Vogel iз співаторами, які дійшли висновку [37], що високу урожайність проса прутоподібного можливо отримати на грунтах 3 низьким або середнім ко- 


\section{СІЛЬСЬКЕ ГОСПОДАРСТВО. РОСЛИННИЦТВО}

нтрольними рівнями поживних речовин, а внесення добрив повинне базуватися в більшій мірі на системі управління посівами.

Отже, на даний час не в повній мірі з'ясовані питання способів основного осіннього обробітку грунту під просо прутоподібне, проведення агротехнічних заходів навесні, ширини міжряддя, особливостей сівби культури та підживлення рослин протягом вегетації в плані збільшення урожайності за сухою біомасою. Тому обране питання, згідно тематики дослідження, є актуальним, потребує детального вивчення, розробки та удосконалення комплексу агрозаходів за вирощування проса прутоподібного.

Мета досліджень - визначити динаміку урожайності проса прутоподібного за сухою біомасою залежно від комплексного застосування елементів технології вирощування.

Відповідно до поставленої мети досліджень передбачалось вирішення наступник завдань:

1. Встановити урожайність біомаси проса прутоподібного залежно від способів осіннього та весняного обробітків грунту;

2. Визначити потенціал урожайності проса прутоподібного залежно від строків сівби та норми висіву насіння;

3. Встановити вплив та ширини міжряддя та підживлення на урожайність біомаси проса прутоподібного.

Методика проведення досліджень. Науковою програмою передбачалося визначення динаміки урожайності проса прутоподібного залежно від елементів технології вирощування: способів обробітку грунту, ширини міжряддя, строків сівби, норми висіву насіння та підживлення.

Комплексний експеримент передбачав проведення наступних багаторічних досліджень.

Дослід 1. «Вплив основного та весняного обробітку грунту на формування урожайності проса прутоподібного» поєднував вивчення фактору А (звичайний обробіток грунту): 1-й варіант - Звичайний обробіток грунту, 2-й варіант - напівпаровий обробіток грунту та фактору Б (весняний обробіток грунту): 1-й варіант - 1 культивація, 2-й варіант - 2 культивації, 3-й варіант - 2 культивації + коткування.

Дослід 2. «Вплив строків сівби і норми висіву насіння на урожайність проса прутоподібного» поєднував вивчення фактору А (строки сівби): 1-й варіант - ранньовесняний, 2-й варіант - весняний, 3-й варіант - пізньовесняний, 4-й варіант - літній та фактору Б (норми висіву насіння): 1-й варіант - 100, 2-й варіант - 200, 3-й варіант 300, 4-й варіант - 400, 5-й варіант - 500 насінин/ $/ \mathrm{M}^{2}$.
Дослід 3. «Формування урожайності проса прутоподібного залежно від ширини міжрядь i підживлення рослин» поєднував вивчення фактору А (ширина міжрядь): 1-й варіант - 15 см, 2-й варіант - 30 см, 3-й варіант - 45 см, 4-й варіант - 60 см та фактору Б (підживлення): 1-й варіант $-\mathrm{N}_{0}$ (контр.), 2-й варіант $-\mathrm{N}_{15}, 3$-й варіант - $\mathrm{N}_{30}, 4$-й варіант $-\mathrm{N}_{45}, 5$-й варіант $-\mathrm{N}_{60}$.

Для закладки експерименту і проведення багатофакторних досліджень в умовах Лісостепу використовували методику дослідної справи в агрономії [2], відповідні наукові методики тарекомендації Н. W. Elbersen [15], М. В. Роїка [12], В. Л. Курила [9] та інших вчених [29].

Досліди були закладені в центральній частині Лісостепу України протягом 2010-2016 рр. на малопродуктивних (маргінальних) землях; грунти мали наступні агрохімічні характеристики: вміст гумусу - 2,07\%; азоту - 44,8; фосфору 65,0 і калію 113,0 мг на 1 кг грунту.

Облік урожайності [38] проводили на час закінчення вегетації рослин шляхом скошування рослин, зважуванням та перерахунку на суху вагу після визначення відсотку вологи.

Отримані результати досліджень, що апробовані в досліді, обробляли за сучасними методами статистики із застосуванням комп'ютерних програм в пакеті Statistaca 6.0.

Результати досліджень. Погодні умови років дослідження були різними за кількістю опадів та середньодобовою температурою повітря і грунту протягом весняно-літнього періоду вегетації проса прутоподібного. В окремі роки фіксували посушливі умови на час відновлення вегетації культури навесні, та відсутність опадів протягом тривалого часу влітку. Це дозволили оцінити реакцію рослин проса прутоподібного на контрастні умови вирощування та особливості їх нівелювання 3 допомогою агрозаходів вирощування культури.

Основний і весняний обробіток грунту. Збільшення кількості технологічних операцій (дві культивації) навесні та проведення коткування до- та після сівби сприяло збереженню вологи у верхніх шарах грунту, що в подальшому впливало на підвищення урожайності проса прутоподібного за сухою біомасою (рис. 1).

Закономірність зміни обсягу біомаси проса прутоподібного залежно від схем передпосівної підготовки грунту спостерігалося і за урожайністю сухої фітомаси, яка варіювала за роками у межах - від 2,4 до 14,7 т/га (одна культивація), від 7,4 до 14,6 т/га (дві культивації), від 7,7 до 15,0 т/га (дві культивації і коткування) на фоні звичайного осіннього обробітку грунту. Необхідно відмітити, що збільшення кількості весняних культивацій (більше двох) не 
призводить до підвищення урожайності. Що пов'язуємо із грануло-механічним станом грунту (пилувата структура) на час сівби культури, зменшеною кількістю сходів (видування і випадання проростків) та погіршенням умов для утворення вторинних коренів рослин. Суттєво більші показники були отримані на варіантах, де проводили напівпаровий обробіток грунту, зміна показника відповідно за варіантами в динаміці за роками дослідження становила: варіант 1 - від 5,8 до 14,4 т/га, варіант 2 від 10,8 до 14,7 т/га та варіант 3 - від 12,3 до 15,5

\section{т/га (рис. 1).}

За встановлення мультиплікаційного (багатомірного) зв'язку між варіантами досліду та продуктивністю сухої біомаси проса прутоподібного виявлено вплив застосування весняних агрозаходів проведених до сівби культури на фоні звичайного та за напівпарового обробітку грунту восени. При цьому встановлено більш суттєвий вплив на урожайність напівпарового основного обробітку грунту, порівняно із звичайним за усіх варіантів досліду (рис. 2).

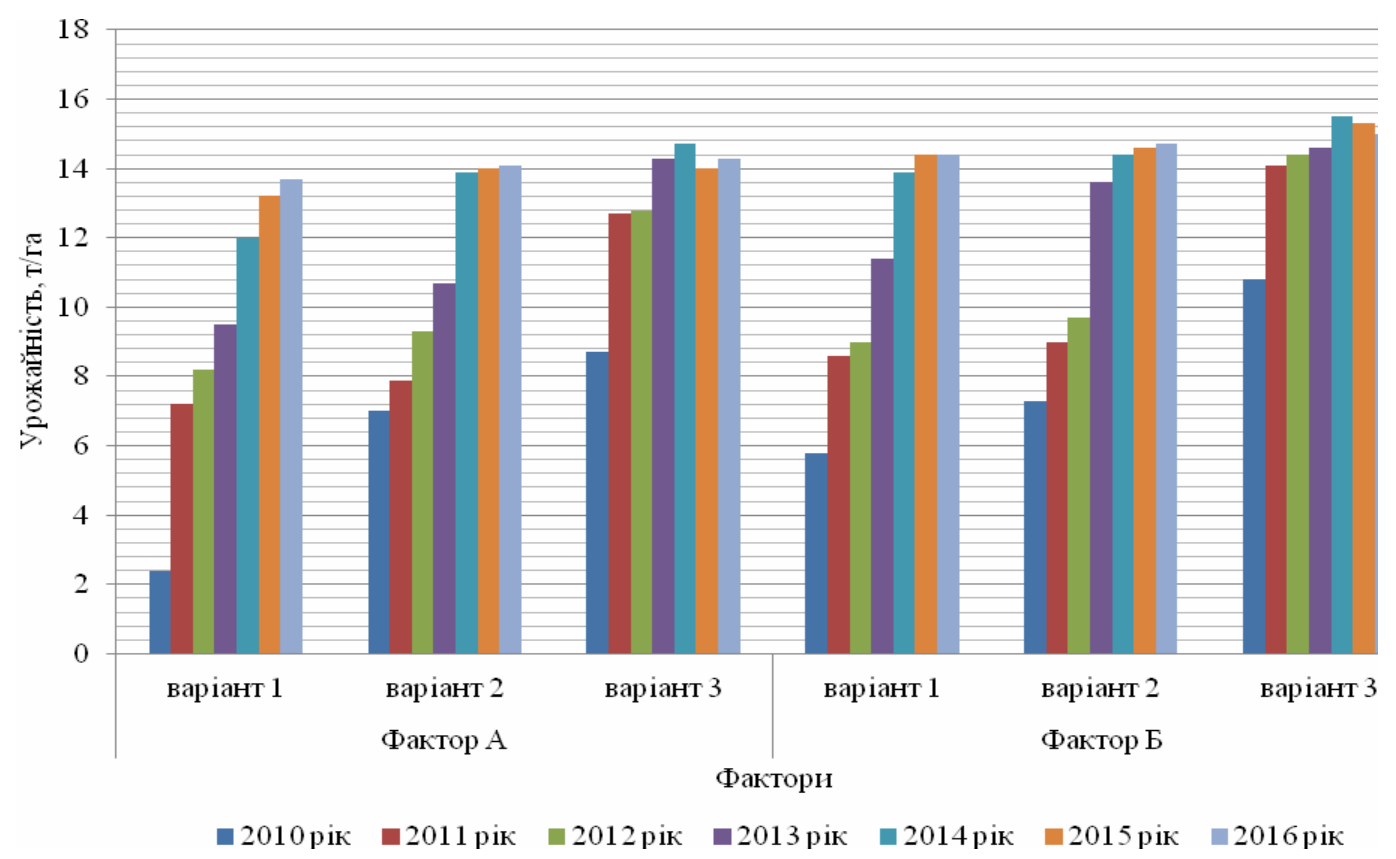

$\mathrm{HIP}_{05}$ (фактор А ) 1,53; HIP 05 (фактор Б) 1,81; HIP 05 (фактор В) 2,08.

Рис. 1. Урожайність сухої біомаси проса прутоподібного залежно від елементів технології вирощування (осінній і весняний обробіток трунту), 2010-2016 рр.

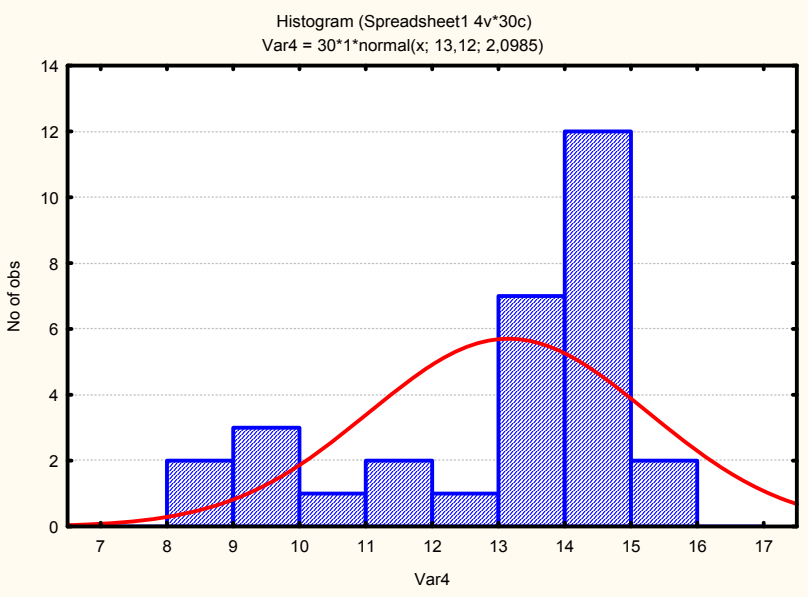

A

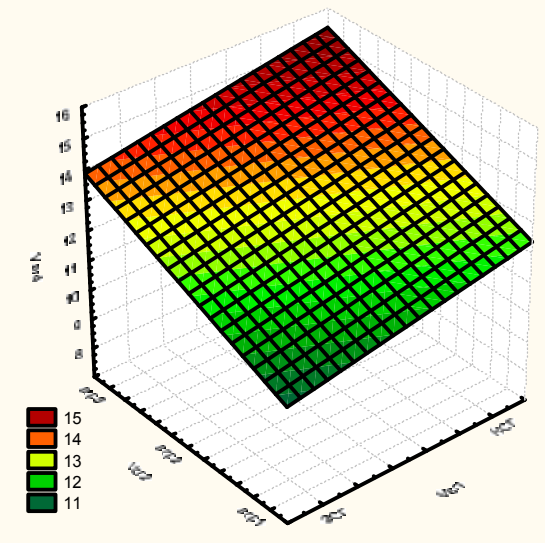

Б

Рис. 2. Логарифмічна (А) та мультиплікаційна (Б) залежнність міжс осіннім і весняним обробімком грунту та урожайністю проса прутоподібного, 2012-2016 рр. 


\section{СІЛЬСЬКЕ ГОСПОДАРСТВО. РОСЛИННИЦТВО}

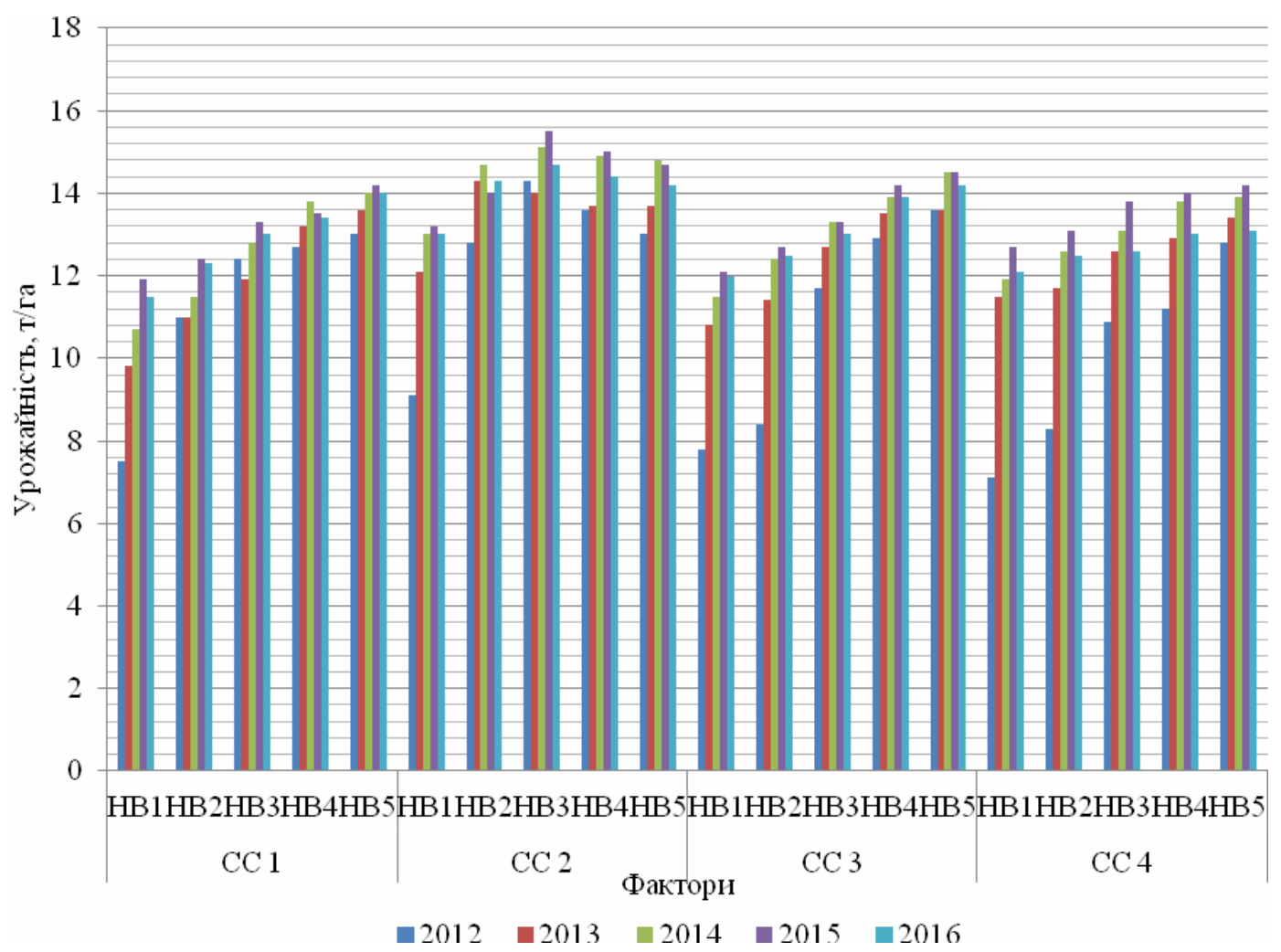

HIP $_{05}$ (фактор А ) 0,95; HIP 05 (фактор Б) 0,91; HIP 05 (фактор В) 1,01.

Рис. 3. Урожайність сухої біомаси проса прутоподібного залежно від елементів технології вирощування (строки сівби і норми висіву насіння), 2010-2016 рр.

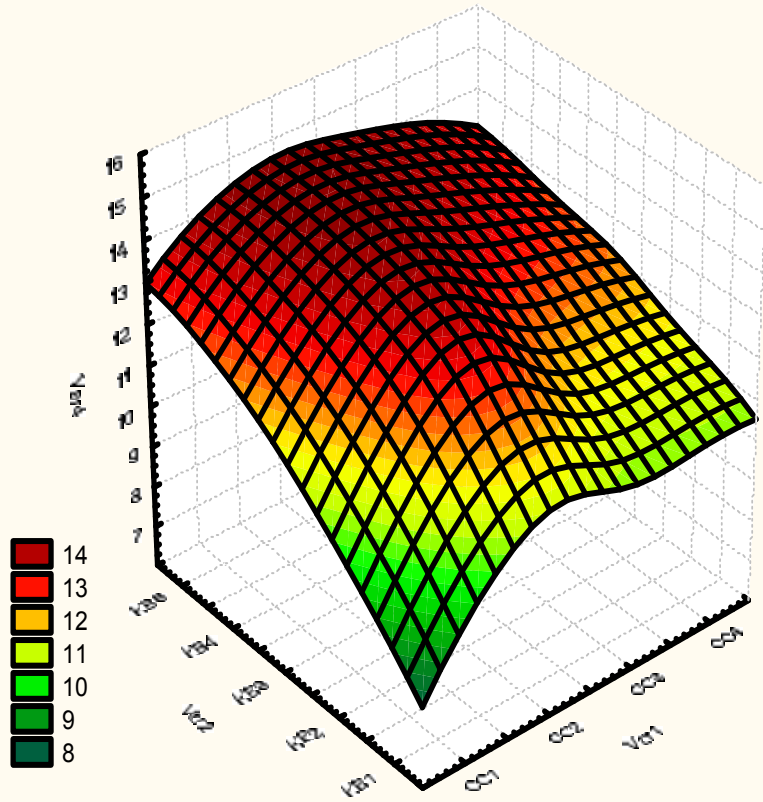

Рис. 4. Залежність між строками сівби і нормами висіву насіння та урожайністю проса прутоподібного, 2012-2016 pp. 


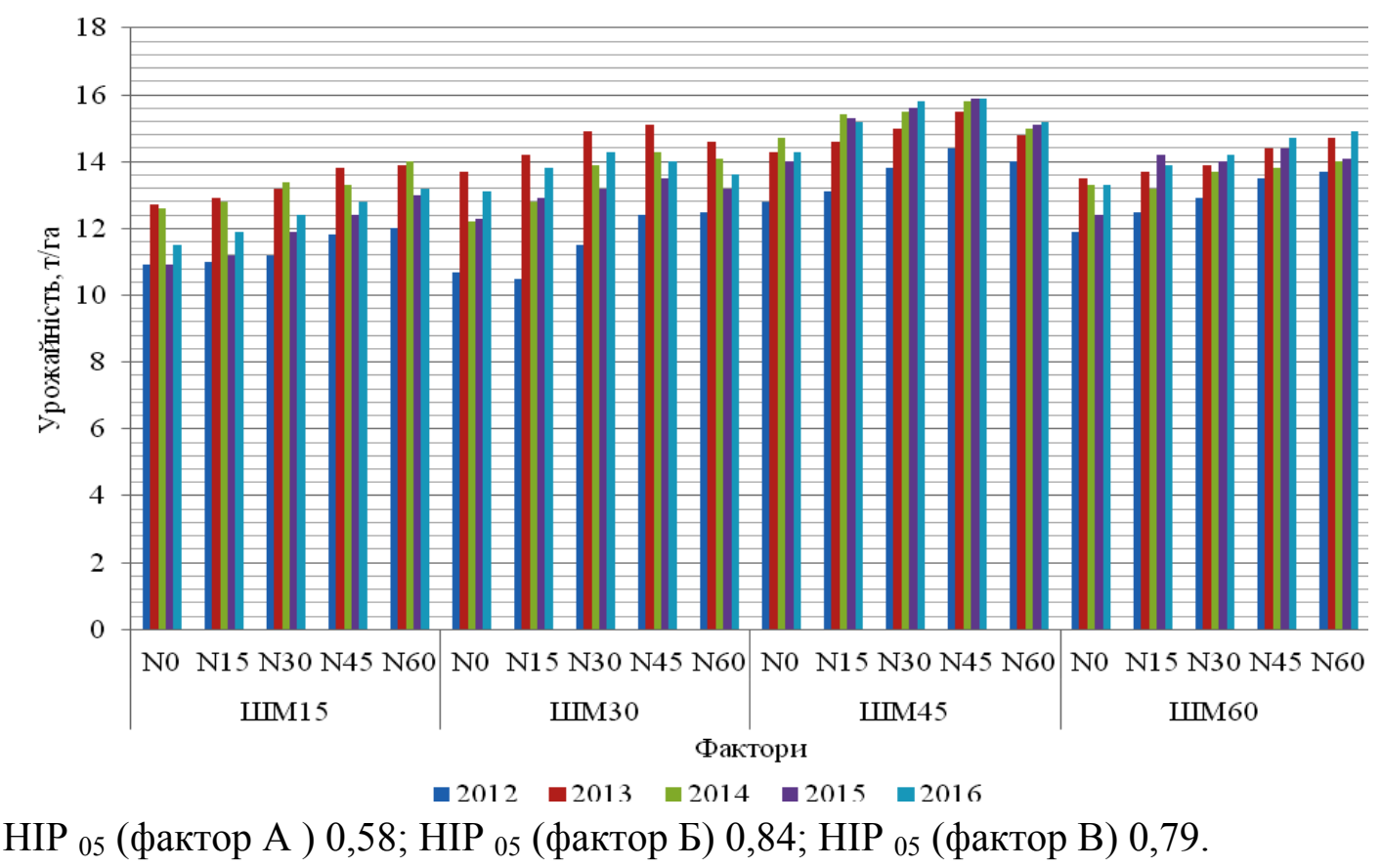

\section{Рис. 5. Урожайність сухой біомаси проса прутоподібного залежно від елементів технологій ви- рощування (иирина міжряддя і підживлення), 2010-2016 рр.}

Частки впливу досліджуваних факторів на урожайність проса прутоподібного. За визначення комплексного впливу агрозаходів на урожайність проса прутоподібного встановлено частки впливу досліджуваних факторів за роки проведення експерименту (рис. 7).

Визначено, що за комплексного впливу агрозаходів на урожайність проса прутоподібного найбільший вплив має ширина міжрядь $(31,2 \%)$, весняний обробіток грунту $(25,4 \%)$ і норма висіву насіння $(25,0 \%)$ та підживлення посівів $(21,9 \%)$ на фоні погодних умов вирощування за роки дослідження $(25,0-50,9 \%)$.

Згідно даних графіка визначено, що збільшення кількості культивацій до двох за проведення весняних технологічних операцій призводить до підвищення урожайності проса прутоподібного на фоні звичайного та напівпарового основного обробітку грунту.

Строки сівби і норми висіву насіння. Варіювання урожайності проса прутоподібного залежно від строків сівби та норми висіву насіння розрізі 2012-2016 років було в межах - від 7,1 до 15,5 т/га. В більшій мірі на рівень значення цього показника мали норми висіву насіння (300 насінин $\left./ \mathrm{M}^{2}\right)$ на фоні весняного строку сівби, порівняно із раннім, пізнім і літним (рис. 3 ).

За ранньовесняного строку сівби урожайність проса прутоподібного змінювалась у межах - від 7,5 до 14,2 т/га, за весняного - від 9,1 до 15,5 т/га, за пізньовесняного - від 7,8 до 14,5 т/га, за літнього - від 7,1 до 14,2 т/га.
При сівбі культури найменшою нормою висіву $\left(100\right.$ насінин/ $\left.\mathrm{m}^{2}\right)$ урожайність проса прутоподібного варіювала залежно від строку сівби - від 7,1 т/га (літній строк) до 13,0 т/га (весняний строк). За максимальної норми висіву (500 насінин/м ${ }^{2}$ ) урожайність культури варіювала залежно від строку сівби - від 13,1 т/га (літній строк) до 14,7 т/га (весняний строк).Графічне відображення залежності між строками сівби і нормою висіву насіння та урожайністю проса прутоподібного наведено на рис. 4.

За другого строку сівби рослини проса прутоподібного формували доказово вищу врожайність вегетативної маси порівняно 3 першим, третім i четвертим. Так за весняного строку сівби, врожайність біомаси у змінювалась від 12,1 т/га (за норми висіву 100 насінин/ $\mathrm{m}^{2}$ ) до 15,5 т/га (за норми висіву 300 насінин $\left./ \mathrm{m}^{2}\right)$ з послідуючим зменшенням показника за норми висіву 400 і 500 насінин $/ \mathrm{M}^{2}$. В той же час відмічено суттєве зменшення урожайності культури при пізньовесняних та літніх строках сівби.

Необхідно відмітити, що відносне збільшення продуктивність культури за збільшених норм висіву насіння на фоні пізніх строків сівби пов'язуємо із несприятливими умовами під час проростання насіння у літній період: зменшена кількість ефективних опадів за одночасно підвищених температурного режиму.

Ширина міжряддя $і$ підживлення. Протягом років дослідження відмічено чітку динаміку збільшення урожайності проса прутоподібного при 


\section{СІЛЬСЬКЕ ГОСПОДАРСТВО. РОСЛИННИЦТВО}

застосуванні азотного підживлення та збільшення площі живлення рослин (до певної межі) за оптимального строку сівби (рис. 5).

Зменшення площі живлення рослин (звужені міжряддя) та внесення на цих варіантах підвищених норм азоту (60 кг/га) призводило до збільшення висоти стеблостою за одночасного зменшення товщини стебел, спостерігалося вилягання рослин - від 14 до $27 \%$ у літній період вегетації.

При цьому кращим варіантом виявилося вирощування культури 3 шириною міжряддя 45 см i застосування весняного підживлення рослин нормою 30-45 кг/га.

Внесення зменшених та збільшених норм азоту не призводить до суттєвого підвищення урожайності, а й навіть зменшує даний показник, за виключенням міжряддя 15 см 3 внесенням 60 кг/га азоту.

Це можна пояснити: конкуренцією рослин за поживні речовини при вирощуванні їх на звужених міжряддях і потреби у підвищених нормах азоту, та виляганні рослин на високих фонах добрив, що пов'язано із збільшенням кількості стебел та зменшенням їх діаметра, i відповідно стійкості до вилягання.

На варіантах із більш ширшими міжряддями 60 см істотної різниці за урожайністю культури між внесенням $\mathrm{N}_{45} \mathrm{i}_{60}$ не виявлено.
Графічне відображення залежності між шириною міжрядь і підживленням та урожайністю проса прутоподібного наведено на рис. 6.

Аналіз даних графіка дозволяє стверджувати, що в більшій мірі на урожайність проса прутоподібного впливає збільшення ширини міжрядь - до 45 см на фоні внесення азотних добрив - від 30 до 45 кг/га із зменшенням даного показника при застосуванні більших норм добрив у підживленні рослин.

Вирощування культури як зменшеній площі живлення рослин (міжряддя $15 \mathrm{~cm})$, так і збільшеній (міжряддя 60 см) призводить до суттєвого зниження урожайності.

Частки впливу досліджуваних факторів на урожайність проса прутоподібного. За визначення комплексного впливу агрозаходів на урожайність проса прутоподібного встановлено частки впливу досліджуваних факторів за роки проведення експерименту (рис. 7).

Визначено, що за комплексного впливу агрозаходів на урожайність проса прутоподібного найбільший вплив має ширина міжрядь (31,2 \%), весняний обробіток грунту $(25,4 \%)$ і норма висіву насіння $(25,0 \%)$ та підживлення посівів $(21,9 \%)$ на фоні погодних умов вирощування за роки дослідження (25,0-50,9\%).

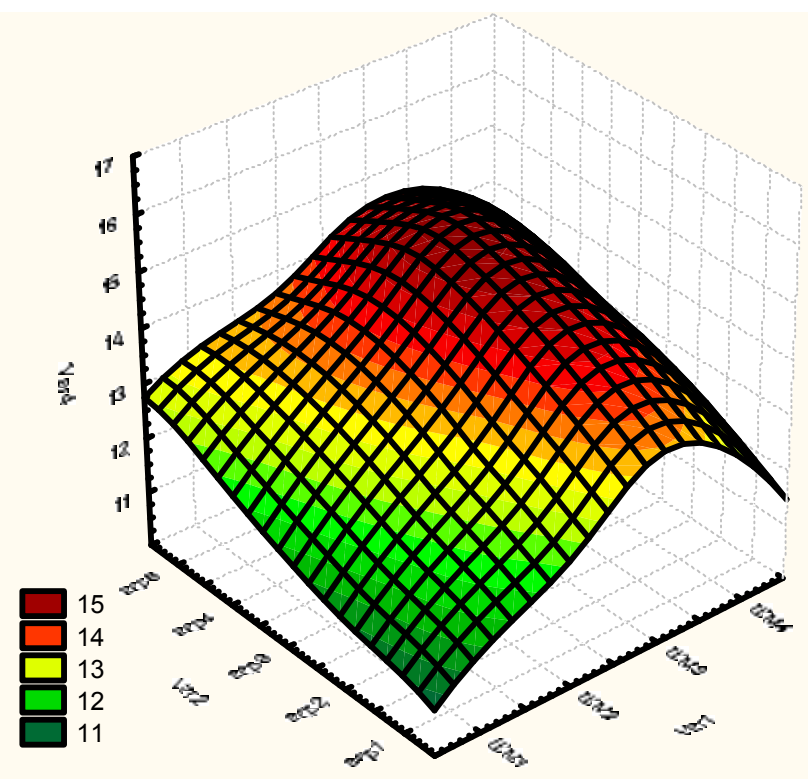

Рис. 6. Залежність між иириною міжрядь і підживленням рослин та урожайністю проса прутоподібного, 2012-2016 рр. 


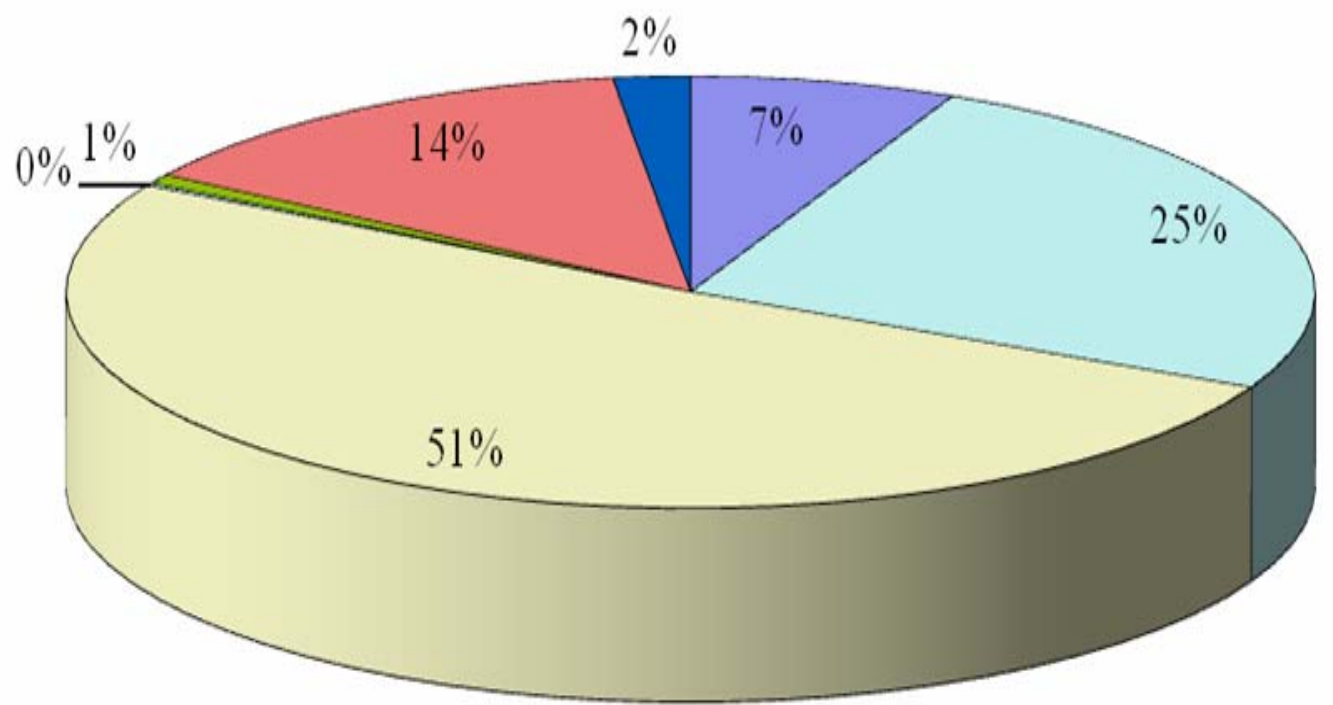

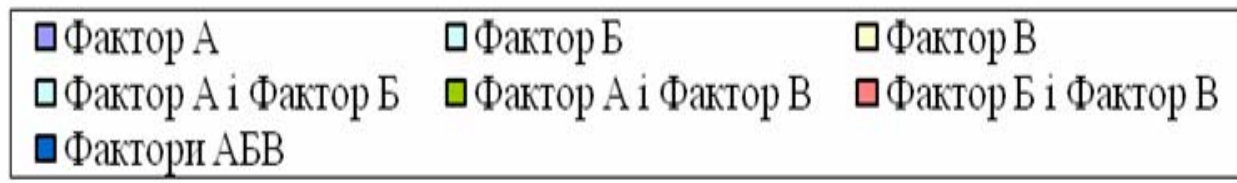

А - основний та весняний обробіток грунту

Примітка: фактор А- осінній обробіток трунту, фактор Б-весняний обробіток трунту, фактор $B$ - рік дослідження.

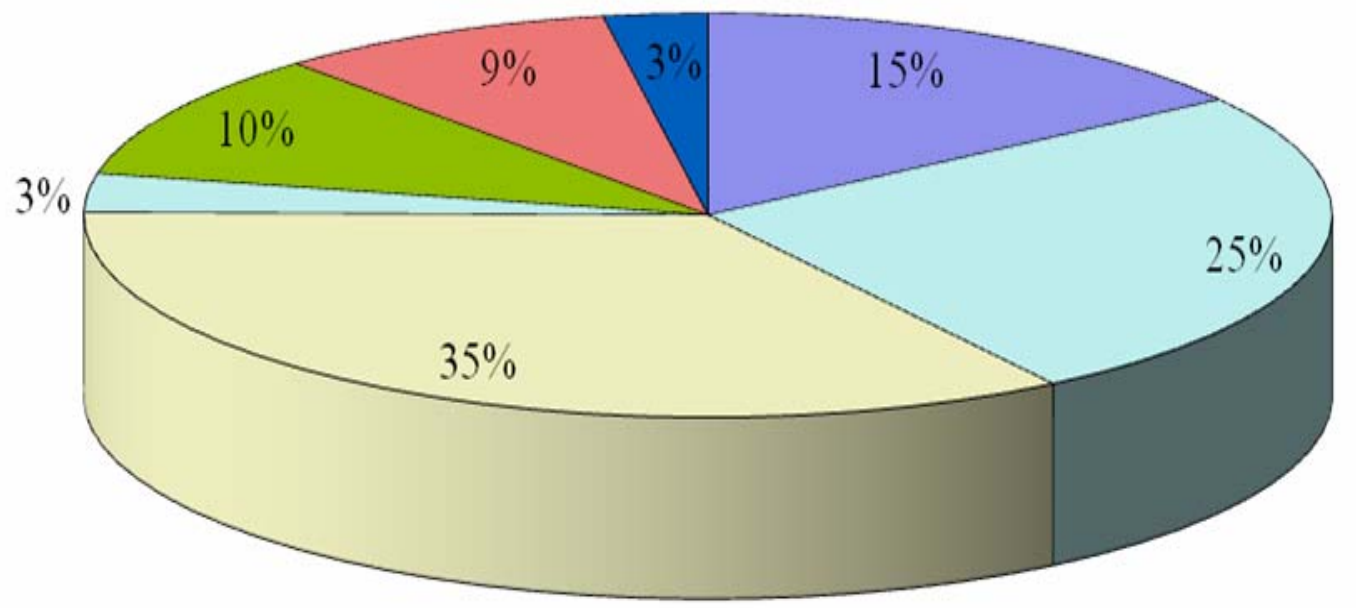

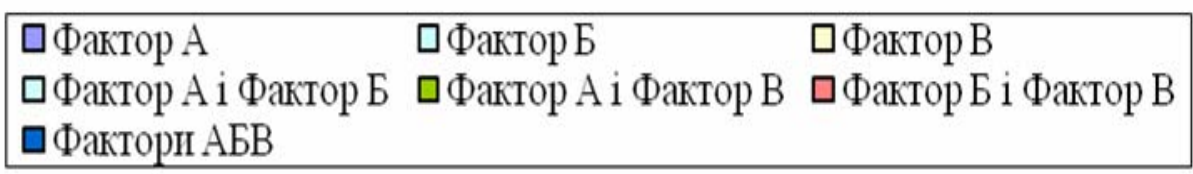

\section{Б - строки сівби і норми висіву насіння} дослідження.

Примітка: фактор A - строк сівби, фактор Б - норма висіву насіння, фактор $B$ - рік 


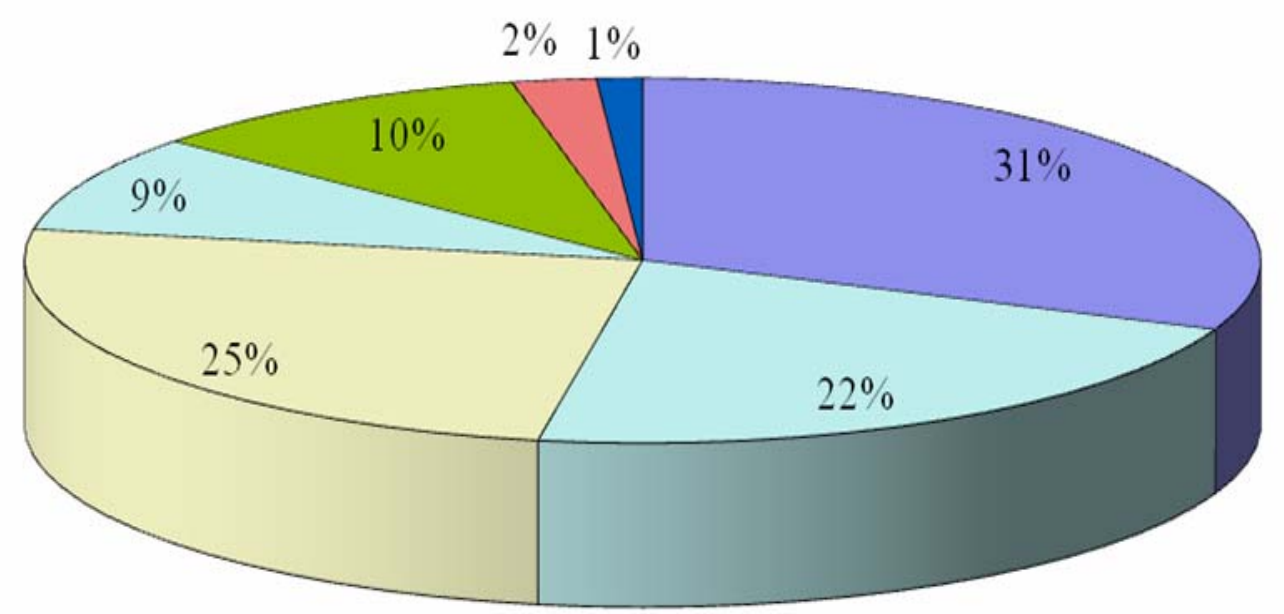

\begin{tabular}{|lll|}
\hline$\square$ Фактор A & 口Фактор Б & 口Фактор B \\
$\square$ Фактор А і Фактор Б & $\square$ Фактор А і Фактор B & 口Фактор Б і Фактор B \\
$\square$ Фактори АБB & & \\
\hline
\end{tabular}

В - ширина міжрядь і підживлення рослин

Примітка: фактор А - иирина міжряддя, фактор Б- підживлення рослин, фактор Врік дослідження.

\section{Рис. 7. Частки впливу досліджуваних факторів (А-основний та весняний обробіток трунту, Б - строками сівби і нормами висіву насіння, В - иирина міжрядь і підживлення рослин) на урожайність проса прутоподібного, 2012-2016 рр.}

Менший вплив на урожайність культури мають строки сівби $(15,0 \%)$ та осінній обробіток грунту $(6,9 \%)$. При цьому визначено, що вагомий вплив на урожайність має взаємодія факторів «весняний обробіток грунту і рік» $(13,9 \%)$, «підживлення і рік» $(10,3 \%)$, «норма висіву і рік» $(8,8 \%)$, «ширина міжряддя і рік» $(8,6 \%)$.

Отже, урожайність проса прутоподібного можливо збільшити завдяки комплексу агротехнічних заходів, що передбачають: проведення своєчасного і якісного обробітку грунту за достатньої кількості культивацій, оптимального строку сівби, норми висіву насіння, надання рослинами достатньої площі живлення та застосування підживлення навесні, що забезпечить умови близькі до сприятливих для росту і розвитку рослин, та дозволить отримувати значний обсяг біомаси 3 одиниці площі.

\section{Висновки:}

1. На фоні напівпарового осіннього обробітку весняна культивація грунту, в подальшому передпосівна культивація з сівбою проса прутоподібного в єдиному технологічному комплексі 3 коткуванням поверхні поля кільчато-зубчастими котками до і після сівби, в порівнянні з варіантами де культивацію проводили один раз, або двічі (без коткування), в посушливих умовах весни сприяла кращому збереженню грунтової во- логи у верхньому шарі грунту. Цей комплекс агрозаходів, порівняно 3 іншими варіантами досліду, дозволив отримати більший рівень урожайності проса прутоподібного за сухою масою.

2. Найбільш доцільним виявилося вирощування проса прутоподібного 3 шириною міжряддя 45 см і застосування весняного підживлення рослин нормою азоту 30-45 кг/га. Внесення зменшених та збільшених норм азоту не призводить до суттєвого підвищення урожайності, а й навіть зменшує даний показник. Аналогічна закономірність відмічена із площею живлення рослин: вирощування культури як на зменшеній площі живлення рослин (міжряддя 15 см), так і збільшеній (міжряддя 60 см) призводить до суттєвого зниження урожайності. Що пов'язуємо із виляганням посівів на звужених міжряддях 3 високих агрофоном добрив.

3. Суттєве більшу урожайності проса прутоподібного отримали за норми висіву насіння 3,0 млн. н./га, як зменшення, так і збільшення даного показника призводить до зниження продуктивності культури. В той же час, порівняно із ранньо-, пізньовесняними та літніми строками сівби відмічено

збільшення урожайності культури при весняному строкові сівби. 


\section{БІБЛІОГРАФІЯ}

1. Гументик М. Я. Агротехнічні прийоми вирощування проса прутоподібного / М. Я. Гументик // Біоенергетика, 2014. - Вип. 1. - С. 30-32.

2. Доспехов Б. А. Методика полевого опыта / Борис Алексеевич Доспехов. - М. : Колос, 1985. $-336 \mathrm{c}$.

3. Думич В. В. Динаміка росту світчграсу в грунтово-кліматичних умовах Полісся України / В. В. Думич, Г. І. Журба, В. Л. Курило // Наукові праці інституту біоенергетичних культур і цукрових буряків, 2013. - Випуск 19. - С. 43-45.

4. Енергетична стратегія України на період до 2030 року // Інформаційно-аналітичний бюлетень «Відомості Міністерства палива та енергетики України». Спеціальний випуск. - 2006. $113 \mathrm{c}$.

5. Звіт «Енергоефективність у промисловості. АПК та ЖКГ»: [Електронний ресурс]. - Режим доступу: http://municipalenergy.org.ua.

6. Кулик M. I. Вплив умов вирощування на кількісні показники рослин світчграсу (Panicum virgatum L.) першого року вегетації / M. I. Кулик // Вісник Полтавської державної аграрної академії, 2012. - Вип. 3 (74). - С. 62-67.

7. Кулик М. I. Вплив ширини міжряддя на формування врожайності сортів проса прутоподібного / М. І. Кулик // Вісник Полтавської державної аграрної академії, 2015. - Вип. 3(78). - С. 6265.

8. Кулик M. I. Урожайність вегетативної надземної маси проса прутоподібного залежно від застосування підживлення / М. І. Кулик // Вісник Полтавської державної аграрної академії, 2017. Вип. 1-2 (77). - С. 13-17.

9. Методичні рекомендації з проведення основного та передпосівного обробітку грунту і сівби проса лозовидного / [Курило В. Л., Гументик М. Я., Гончарук Г. С. та ін.]. - К. : Інститут біоенергетичних культур і цукрових буряків НААН, 2012. $-26 \mathrm{c}$.

10. Мороз О. В. Світчграс як нова фітоенергетична культура / [О. В. Мороз, В. М. Смірних, В. М. Курило та ін.] // Цукрові буряки, 2011. - Вип. №3 (81). - C. 12-14.

11. Поліщук М. I. Вплив строків сівби і ширини міжряддя на продуктивність біомаси світчгpacy / М. І. Поліщук, Б. М. Ковбасюк // Сільське господарство та лісництво, 2016. - Вип. 3. - С. 266-271.

12. Роїк М. В. Методика проведення експертизи сортів проса прутоподібного (Panicum virgatum L.) на відмінність, однорідність і стабільність : Код UPOV : PANIC_VIR / [M. В. Роїк,
Д. Б. Рахметов, С. М. Гонтаренко та ін.]. - К. : УIECP, 2012. - $15 \mathrm{c}$.

12. Agostini F., Gregory A. S., Richter G. M. (2015) Carbon sequestration by perennial energy crops: is the jury still out. Bioenerg Res. 8 : 10571080.

13. Bransby D. I., Walker R. H and M. S. Miller (1997) Development of optimal establishment and cultural practices for switchgrass as an energy crop. Five year summary report. Oak Ridge National Laboratory, Oak Ridge, TN.

14. Christian D. G. and H. W. Elbersen (1998) Switchgrass (Panicum virgatum L.). In: N. El Bassam ed. Energy plant species: Their use and impact on environment and development. London: James and James publishers, 257-263.

15. Elbersen H. W., Christian D. G., El Bassam N., Sauerbeck G., Alexopoulou E., Sharma N., Piscioneri I. (2004) A Management Guide for planting and production of Switchgrass as a biomass crop in Europe. Proceeding of 2nd World Conference on Biomass for Energy, Industry and Climate Protection. Rome, Italy. 10-14 May 2004. Available

http://library.wur.nl/WebQuery/wurpubs/380256

16. Elbersen H. W., Kulyk M., Poppens R., at al. (2013) Switchgrass Ukraine : overview of switchgrass research and guidelines Wageningen : Wageningen UR. Food \& Biobased Research. $-26 \mathrm{p}$.

17. Elbersen H. W., Ocumpaugh W. R., Hussey M. A., Sanderson M. A. and C. R. Tischler (1998). Switchgrass and kleingrass crown node elevation under low light. Crop. Sci. 38: (May-June issue).

18. Elbersen Wolter, Tijs M. Lammens, Eija A. Alakangas, Bert Annevelink, Paulien Harmsen, Berien Elbersen (2017) Chapter 3-Lignocellulosic Biomass Quality: Matching Characteristics With Biomass Conversion Requirements. Modeling and Optimization of Biomass Supply Chains. Top Down and Bottom Up Assessment for Agricultural, Forest and Waste Feedstock. 2017, Pages 55-78. Available at: $\quad$ https://doi.org/10.1016/B978-0-12-8123034.00003-3

19. Flaspohler D. J., Froese R. E., Webster C. R. (2008). Biomass, Bioenergy and Biodiversity: A review of key issues for terrestrial and aquatic ecosystems : 133-162 in: B. D. Solomon and V. A. Luzadis (eds.), Renewable Energy from Forest Resources in the United States.

20. Jung G. A., Shaffer J. A. and W. L. Stout (1988) Switchgrass and big bluestem responses to amendments on strongly acid soil. Agron. J. 80 : 669-676. 
21. Jung G. A., Shaffer J. A., Stout W. L. and M. T. Panciera (1990) Warm-season grass diversity in yield, plant morphology, and nitrogen concentration and removal in Northeastern USA. Agron. J. 82 : 21-26.

22. Kulyk M. Impact of seeding terms and row spacing on yield of switchgrass phytomass, biofuel and energy output. Annals of Agrarian Science. Vol. 14 , Issue $4: 331-334$.

23. Kulyk M. Methods of calculation productivity phytomass for switchgrass in Ukraine / M. Kulyk, W. Elbersen. - Poltava, 2012. - 10 p.

24. Lee D. K., Owens V. N., Doolittle J. J. (2007) Switchgrass and soil carbon sequestration response to ammonium nitrate, manure, and harvest frequency on conservation reserve program land // Agron J. 99 : 462-468.

25. Ma Z., Wood C. W. et al. (2001) Impact of row spacing, nitrogen rate, and time on carbon partitioning of switchgrass. Biomass and Bioenergy. $20: 413-419$.

26. Myers R. E. and J. Dickerson (1984). How to plant and maintain switchgrass. As nesting and winter cover for pheasants and other wildlife. NY Department of Agriculture / NY Soil Conservation Service NY-63.

27. Moser L. E., Vogel K. P. (1995) Switchgrass, Big Bluestem and Indiangrass. In: R. F. Barnes, D. A Miller, C. J. Nelson eds. Forages. An introduction to grassland agriculture. 5 th ed. Ames : Iowa University Press. 409-420.

28. Ocumpaugh W. R., Sanderson M. A., Hussey M. A., Read J. C., Tischler C. R. and R. L. Reed (1997) Evaluation of switchgrass cultivars and cultural methods for biomass production in the southcentral U.S. Final report. Oak Ridge National Laboratory, Oak Ridge, TN. contract \#19X-SL128C.

29. Parrish D. J., Fike J. H. (2009) Selecting, Establishing, and Managing Switchgrass (Panicum virgatum) for Biofuels. In: Mielenz J. (eds) Biofuels. Methods in Molecular Biology (Methods and Protocols), vol 581. Humana Press, Totowa, NJ. pp. 27-40. Available at: https://link.springer.com/protocol/10.1007/978-160761-214-8_2.

30. Samson R., Delaquis E., Deen B., DeBruyn J.

\section{ANNOTATION}

Kulyk M. Analysis of the complex influence of agrotechnological techniques on the switchgrass yield in the condition of the Central Forest-Steppe of Ukraine.

Alternative resource of energy crops (including and Eggimann U. (2016) Switchgrass. ·Agronomy : book. Ontario, $2016: 82$ pages.

31. Samson R., Girouard P. and Y. Chen (1997) Evaluation of switchgrass and short rotation forestry willow in eastern Canada as bio-energy and agrifibre feedstocks. In: R. P. Overend and E. Chornet (eds.) Proceedings of the third conference of the Americas. Making a business from biomass in energy, environment, chemical, fibers and materials, Montreal, Canada. P. 145-151.

32. Sanderson M. A, Reed R. L., Mclaughlin S. B. et al. (1996) Switchgrass as a sustainable bioenergy crop. Bioresour Technol. $56: 83-93$

33. Smart A. J. and L. E. Moser (1997) Morphological development of switchgrass as affected by planting date. Agron. J. 89 : 958-962.

34. Tulbure M. G., Wimberly M. C., Boe A., Owens V. N. (2012) Climatic and genetic controls of yields of switchgrass, a model bioenergy species. Agric Ecosyst Environ. 146 : 121-129.

35. Turhollow A. F. (1991) Screening herbaceous lignocellulosic energy crops in temperate regions of the USA. Bioresource Technology. $36: 247-252$.

36. Vassey T. L., George J. R. and R. E. Mullen (1985) Early-, mid-, and late-spring establishment of switchgrass at several seeding rates. J. Agron. 77 : 253-257.

37. Vogel K. P, Brejda J. J., Walters D. T., Buxton D. R. (2002) Switchgrass biomass production in the Midwest USA: harvest and nitrogen management. J. Agron. 94 : 413-420.

38. Wang D., Leabauer D. S., Dietze M. C. (2010). A quantitative review comparing the yield of switchgrass in monocultures and mixtures in relation to climate and management factors. GCB Bioenergy, 2 : 16-25. Available at: doi: 10.1111/j.1757-1707.2010.01035.x.

39. Wolf D. D., Fiske D. A. (2009) Planting and managing switchgrass for forage, wildlife, and conservation // Virginia Cooperative Extension, publication. 418-013. Available at: http://pubs.ext.vt.edu/418/418-013/418-013_pdf.pdf.

40. Wullschleger S. D., Sanderson M. A., McLaughlin S. B., Biradar D. P. and A. L. Rayburn. (1996) Photosynthetic rates and ploidy levels among populations of switchgrass. Crop Sci. $36: 306-312$.

switchgrass) involvement to fuel and energy complex of Ukraine is a critical problem at present. Energy crops' sowings management increases yield and oil equivalent output within the certain area of energy crop plot of land. That is why determination 
of the most influencing agrotechnological techniques (for cultivation technology elements improvement) over switchgrass yield is an important issue and requires a more complicated study.

Research purpose is to determine switchgrass yield depending upon complex application of the cultivation technology elements. The agricultural experimental methods as well as proper theoretical and practical recommendations of switchgrass cultivation given by Wolter Elbersen, M. V. Roik, V. L. Kurylo and other scientists have been used in order to lay out the experiment and perform multiple-factor researches in the Forest-Steppe area. Obtained research results have been processed by application of Statistics computer programs.

Change of switchgrass yield depending upon schemes of pre-sowing soil tillage has been observed. Switchgrass yield varied according to years in the range from 2.4 to 14.7 tons per hectare (1 cultivation), from 7.4 to 14.6 tons per hectare (2 cultivations), from 7.7 to 15.0 tons per hectare ( 2 cultivations and rolling) with general autumn soil tillage. Substantially higher indices have been provided on the options with semi-steam soil tillage, change of yield on the options according to the years was: option 1 - from 5.8 to 14.4 tons per hectare, option 2 from 10.8 to 14.7 tons per hectare and option 3 from 12.3 to 15.5 tons per hectare.

Dynamic of switchgrass yield growth applying nitrogen additional fertilizing and increasing the area of plant nutrition with optimal sowing term has been fixing within the experiment years. The best option was the option of switchgrass cultivation with row-spacing of $45 \mathrm{~cm}$ and application of spring additional fertilizing with dosing of $45 \mathrm{~kg} / \mathrm{ha}$. Applying less or bigger nitrogen dosing does not cause considerable yield increase, but even lessens this index except option with row-spacing of $15 \mathrm{~cm}$ and nitrogen application of $60 \mathrm{~kg}$ per hectare. It can be explained by plant competition for nutrients while growing them on narrow row-spacings and needs in higher nitrogen dosing. Although, there was not huge difference between application of $\mathrm{N}_{45}$ and $\mathrm{N}_{60}$ on the options with wider row-spacing of $60 \mathrm{~cm}$.

The maximum productivity the switchgrass depending on the sowing time was 3.0 million seeds on hectares. It is determined that the decrease, and an increase in this indicator leads to a decrease in crop productivity.

Substantial influence of spring agrotechnological techniques performed before crop sowing process on the background of general and semi-steam soil tillage in autumn has been discovered on the basis of multivariate connection between the experiment options and yield of switchgrass dry biomass. Also, it has been established that the method of soil tillage as well as nitrogen additional fertilizing in spring had more significant influence on switchgrass yield.

Key words: switchgrass, soil tillage, row-spacing width, sowing term, additional fertilizing, yield. 